\title{
COMPETENCIES AND CHALLENGES OF DEPED TEACHERS IN THE K TO 12 SCIENCE CURRICULUM IMPLEMENTATION
}

\author{
Maria Wendy M. Solomo, Ed.D. \\ Assistant Professor, Partido State University, Goa, Camarines Sur, Philippines
}

Article DOI: https://doi.org/10.36713/epra6744

DOI No: $10.36713 /$ epra6744

\begin{abstract}
-ABSTRACT
Curriculum reforms are implemented in various countries to improve their educational system. This article presents the teaching competencies, needs and challenges encountered by the Department of Education (DepEd) Science teachers in Partido District, Camarines Sur, Philippines along with the implementation of the $K$ to 12 Science curriculum. It employed the descriptive method of research and administered the researcher-made instrument to 49 DepEd Science teachers. The majority of the teachers rated themselves with very high competencies in Earth Science and Biology and high competencies in Chemistry and Physics, however some expressed need to further deepen their understanding in some concepts such as Light and Electricity, Circular Motion, Projectile Motion, Conservation of Linear Momentum, and Concentration of Solutions. Teachers attain proficiency of a more complex competency if they acquire proficiency of preceding competencies. The availability of instructional materials and the "concept of experience" help teachers have a better grasp of science concepts. Continued support from the government and other stakeholders is needed to address the perennial problems/challenges that DepEd teachers encountered.
\end{abstract}

KEYWORDS: challenges, competencies, DepEd teachers, pedagogical knowledge, Science curriculum

\section{INTRODUCTION}

A highly-educated society is key for a country to attain economic growth and development. Several countries implement curriculum reforms to create more productive professionals to contribute to their society. Indeed, John F. Kennedy once said that a country should invest in quality education to produce a brilliant, competitive and strong labor force to attain economic progress. In the implementation of new curriculum reforms and academic programs, it is possible that the institution might be facing problems, difficulties and challenges. Cheung and Wong (2012) cited that the curriculum reform in Hong Kong faced several key obstacles and challenges that were common in many other countries, in the implementation stage, such as teachers' heavy workloads, learning diversity in class, and teachers' inadequate understanding of the reform.

In the Philippines, the K to 12 Basic Education Program was implemented in phases starting school year (SY) 2012-2013 and fully implemented in SY 2017-2018 to improve its educational system. One of the salient features of the program is ensuring integrated and seamless learning (spiral progression) where science concepts and skills in Life Sciences, Physics, Chemistry, and Earth Sciences are presented from low to high levels of complexity to have a deeper understanding of core concepts. In the spiral curriculum, science educators design lessons, activities and performance tasks that honed the higher-order thinking skills and dispositions of the learners (Martin, cited in Resurrecccion and Adanza, 2015).

Cabansag (2014) cited that the impact statements of teachers, students and parent-respondents suggest the need for close monitoring of the program implementation and provision of continuous professional training for teachers to clear areas of misinterpretations. According to Ferido (2015) of UP NISMED, monitoring should assess the implementation of the curriculum and its effects. Capilitan, et al. (2016) mentioned that Romulo (2015), Capangpangan (2015), and Ocampo (2015) determined the issues on the implementation of the K to 12 Curriculum in Cagayan de Oro City, and Iligan City. Likewise, Capilitan et al. reviewed the issues in the implementation of the $\mathrm{K}$ to 12 Science Curriculum and pointed out that the previous lessons are very essential to 
build up the knowledge to be connected to the next lesson. They further emphasized the importance of strengthening the basic concepts from lower years so that the students and teachers will have their smooth mainstreaming to the next lesson. For instance, if a Grade 7 teacher fails to discuss the basic concepts of work and energy, the Grade 8 teacher will have difficulty discussing and deepening the lessons on work and energy. Understanding the lesson on work and energy should grow in breadth and depth.

Although Shahani (2015) cited that DepEd has been conducting numerous teacher training to address these concerns, there is a sense that things remain confused and unsettled. She further asserted that most likely, uneasiness and suspicion among teachers will linger until the new system is in place and they have a chance to work through it and make the needed adjustments.

The CHED Memorandum Order No. 75 Series of 2017 on policies, standards, and guidelines for Bachelor of Secondary Education (BSEd) following the pertinent provisions of RA No. 7722 and in pursuance of outcomes-based quality assurance as advocated under CMO No. 46 s. 2012 was just implemented in the academic year 2018-2019. The said curriculum for Bachelor of Secondary Education (BSEd) particularly in the field of Sciences has been revised or changed in consonance with the $\mathrm{K}$ to 12 Program Implementation. However, how can the present teachers deepen the understanding of science concepts and their application to real-life situations if they are not equipped with the necessary skills and teaching competencies? Take note that teachers have the greatest influence on the students' academic performance (Hattie, 2003).

With this, the study determined the competencies, skills and challenges encountered by DepEd teachers along with the implementation of the Science curriculum. When teachers are aware of their competencies, they could do something to enhance their less mastered teaching competencies. Likewise, the Department of Education and other concerned agencies could address their issues, concerns, and difficulties they encountered in implementing the said curriculum.

\section{METHODOLOGY}

The study employed the descriptive method of research to investigate the competencies and challenges encountered by DepEd Junior High school Science teachers. It utilized both primary and secondary data. Primary data were collected using survey questionnaires and interviews. The questionnaire measures the teachers' competencies in Earth Science, Chemistry, Biology, and Physics, their technical skills and the encountered challenges. The teaching competencies were derived from $\mathrm{K}$ to 12 Science curriculum guide. Moreover, documents such as the list of secondary schools and $\mathrm{K}$ to 12 Science curriculum guide were utilized as secondary data. The locale of the study was the selected DepEd schools in the $4^{\text {th }}$ congressional districts of Camarines Sur, Philippines.

In the implementation of the $\mathrm{K}$ to 12 Science curriculum, DepEd teachers were provided modules, a Science curriculum guide, and learning resources that could be downloaded in their DepEd portal. Although teachers follow the same module, there is a necessity to assess teachers' competencies since teachers play an important role in the students' academic achievement. Hence, in this study, teachers did self-evaluation which was verified by their principal/immediate superior through classroom observation.

Before gathering the data, communication was sent to the principals of the 12 participating schools to seek permission to conduct the research. A consent letter was distributed to the respondents and the research was conducted based on voluntary participation. All Science teachers from these 12 schools participated in the study. Principals, Science coordinators and subject teachers were interviewed to validate the results of the survey.

\section{Teaching competencies of DepEd Science teachers \\ RESULTS AND DISCUSSION}

Teachers' competencies are measured in terms of content knowledge and skills in Earth Science, Chemistry, Physics, and Biology. Grade 7 teachers had the highest competencies in Biology and lowest in Physics. They had very high competency in identifying the parts and functions of the microscope, focusing specimens under a compound microscope, and explaining why the cell is considered the basic structural and functional unit of all organisms. According to them, their schools have several microscopes which are utilized for classroom instruction that help them become proficient at identifying its parts and functions. Availability of instructional materials helps in mastering a certain competency hence, government support plays an important role in securing learning resources that could be distributed to different public schools. 
Table 3: Grade 7 teaching competencies

\begin{tabular}{lcccc}
\hline \multicolumn{1}{c}{ Parameter } & \multicolumn{4}{c}{ Level of Competency (Weighted Mean) } \\
& Earth & Biology & Chemistry & Physics \\
& Science & & & \\
\hline Content & 4.35 & 4.40 & $4.16(\mathrm{H})$ & $4.11(\mathrm{H})$ \\
Knowledge & $(\mathrm{VH})$ & (VH) & & \\
Skills & 4.38 & 4.47 & $4.26(\mathrm{VH})$ & $4.09(\mathrm{H})$ \\
& $(\mathrm{VH})$ & $(\mathrm{VH})$ & & \\
\hline
\end{tabular}

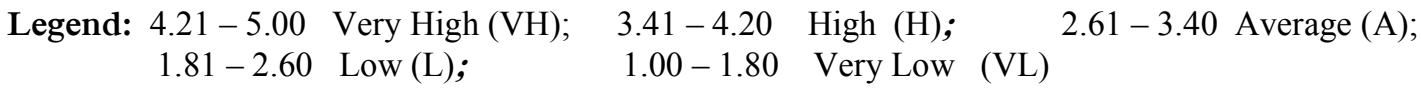

On the other hand, Grade 7 teachers got the lowest rating in relating the characteristics of light such as color and intensity to frequency and wavelength and explaining the importance of earthing or grounding. This competency requires mastery of previous concepts. How could a person relate the characteristics of light to frequency and wavelength, if he/she doesn't have a full grasp of the nature of light? Competencies are presented in spiral progression from less to more complex thus, there is a need to become proficient at basic competencies before mastering higher competencies. In fact, Taber (2012) stressed the significance of building understanding in spiral progression. Exploring and deepening the concepts about light, frequency and wavelength using simulation and video presentations are highly encouraged.

Grade 8 teachers had the highest competencies in Earth Science and lowest in Chemistry as reflected in Table 4. They got the highest competency in explaining how typhoons are formed, tracing the path of typhoons that enter the Philippine Area of Responsibility (PAR) using a map and tracking data, and explaining how earthquakes are generated. Teachers had full mastery of the said topics due to their exposure and experience with typhoons and earthquakes. It is not surprising because the Philippines is one of the most disaster-prone countries in the world, having almost all types of natural hazards. These experiences with typhoons and earthquakes made them understand how they are developed. Experience is indeed the best teacher.

Table 4: Grade 8 teaching competencies

\begin{tabular}{lcccc}
\hline \multicolumn{1}{c}{ Parameter } & \multicolumn{3}{c}{ Level of Competency (Weighted Mean) } \\
& $\begin{array}{c}\text { Earth } \\
\text { Science }\end{array}$ & Biology & Chemistry & Physics \\
\hline Content & 4.44 & 4.35 & $4.16(\mathrm{H})$ & 4.22 \\
Knowledge & $(\mathrm{VH})$ & $(\mathrm{VH})$ & & $(\mathrm{VH})$ \\
Skills & 4.41 & 4.32 & $4.16(\mathrm{H})$ & 4.23 \\
& $(\mathrm{VH})$ & $(\mathrm{VH})$ & & (VH) \\
\hline
\end{tabular}

Legend: $\quad 4.21-5.00 \quad$ Very High $(\mathrm{VH}) ; \quad 3.41-4.20 \quad$ High $(\mathrm{H})$; $1.81-2.60$ Low $(\mathrm{L}) ; \quad 1.00-1.80 \quad$ Very Low $(\mathrm{VL}$

$2.61-3.40$ Average (A);

However, they had the lowest competencies in making diagrams showing the forces acting on a particular body and relating the laws of motion to bodies in a uniform circular motion. These competencies require a full grasp of the types of forces, the three laws of motion and circular motion. Those teachers who had difficulty illustrating the forces acting on an object using diagrams and could hardly relate laws of motion to circular motion are not Physics teachers based on their academic preparation. Collaboration and sharing of expertise and resources with other Science teachers are the keys to address this kind of challenge.

Grade 9 teachers, who are BSEd/BS Biology graduates, had the highest competency in Biology and lowest in Physics (Table 5). They are very conversant in explaining how the respiratory and circulatory systems work together to distribute the nutrients, gases, and other molecules to and from the different parts of the body and inferring how lifestyle affects these two systems. Teachers had a better grasp of the Science concept when they themselves experience these body processes namely: respiration and blood circulation. This is in accordance with Kolb's (1984) experiential learning theory that knowledge is created through the transformation of experience.

Conversely, the majority of Grade 9 teachers had the lowest competencies in examining effects and predicting causes of collision-related damages/injuries and investigating the relationship between the angle of release and the height and range of the projectile. Investigating the effects and causes of collision-related injuries requires a deep understanding of other physics concepts namely: projectile motion, impulse, momentum, and conservation of linear momentum. How can a teacher attain proficiency of a certain competency if he/she fails to acquire proficiency of preceding competencies? It should be noted that the levels 
of complexity of Science concepts from one grade level to another level increase hence, a deeper understanding of core concepts and higher competencies are required in Grade 9. Furthermore, content knowledge, which is primarily dependent on teachers' preparation, affects the students' academic performance (Hill, et al., 2005; Baumert et al., 2010; Voss, et al., 2011). Attendance in master's degree programs will help teachers upgrade and enhance their knowledge and skills in teaching.

Table 5: Grade 9 teaching competencies

\begin{tabular}{lcccc}
\hline \multicolumn{1}{c}{ Parameter } & \multicolumn{4}{c}{ Level of Competency (Weighted Mean) } \\
& $\begin{array}{l}\text { Earth } \\
\text { Science }\end{array}$ & Biology & Chemistry & Physics \\
& 4.27 & 4.32 & $4.08(\mathrm{H})$ & $3.78(\mathrm{H})$ \\
Content & (VH) & (VH) & & \\
Knowledge & $4.02(\mathrm{H})$ & 4.32 & $3.84(\mathrm{H})$ & $3.70(\mathrm{H})$ \\
Skills & & $(\mathrm{VH})$ & & \\
& & &
\end{tabular}

Legend: $\quad 4.21-5.00 \quad$ Very High $(\mathrm{VH}) ; \quad 3.41-4.20 \quad$ High $(\mathrm{H}) ; \quad 2.61-3.40$ Average (A); $1.81-2.60$ Low $(\mathrm{L}) ; \quad 1.00-1.80$ Very Low (VL

Grade 10 teachers had the highest competencies in Earth Science and lowest in Chemistry (Table 6). They had the highest competencies in describing the distribution of active volcanoes, earthquake epicenters, and major mountain belts, describing the different types of plate boundaries and enumerating the lines of evidence that support plate movement. These competencies do not require complex knowledge or skills and the needed data are accessible online. Internet connection is necessary to have access to numerous learning resources, statistical data and other information that are readily available on the web.

Table 6: Grade 10 teaching competencies

\begin{tabular}{lcccc}
\hline \multicolumn{1}{c}{ Parameter } & \multicolumn{4}{c}{ Level of Competency (Weighted Mean) } \\
& Earth & Biology & Chemistry & Physics \\
& Science & & & \\
\hline Content & 4.39 & 4.29 & $4.11(\mathrm{H})$ & $4.19(\mathrm{H})$ \\
Knowledge & $(\mathrm{VH})$ & $(\mathrm{VH})$ & & \\
Skills & 4.28 & $4.17(\mathrm{H})$ & $3.89(\mathrm{H})$ & $4.20(\mathrm{H})$ \\
& $(\mathrm{VH})$ & & & \\
\hline
\end{tabular}

Legend: $\quad 4.21-5.00 \quad$ Very High $(\mathrm{VH}) ; \quad 3.41-4.20 \quad$ High $(\mathrm{H}) ; \quad 2.61-3.40$ Average (A); $1.81-2.60$ Low $(\mathrm{L}) ; \quad 1.00-1.80 \quad$ Very Low $(\mathrm{VL}$

On the other hand, recognizing the major categories of biomolecules such as carbohydrates, lipids, proteins, and nucleic acids ranked last. Some teachers claimed that recognizing the categories of biomolecules requires a full grasp of the structure and composition of each type. It could be elicited that teachers will have difficulty mastering a certain competency if they fail to understand prerequisite topics. It is in accordance with the ideas of Bruner (1960) that to make learning "progressive", it must be based on previous learning.

\section{PEDAGOGICAL KNOWLEDGE OF SCIENCE TEACHERS}

Teachers have very high pedagogical knowledge in terms of lesson planning, instructional delivery, and the art of questioning (Figure 1). Along with lesson planning, teachers got the highest competencies in using measurable objectives which are directed to student needs and writing lessons in an organized, coherent, thorough, and grade-appropriate. In formulating learning objectives, they were aware that they should be specific, measurable, attainable, realistic, and time-bound. A well-planned lesson is rooted in well-formulated objectives and could be reflected in the delivery of the lesson, particularly in the learning resources, strategies used, and assessment given by the teacher. This particular pedagogical knowledge could be acquired by teachers during teacher education (König, et al., 2011).

In terms of instructional delivery, providing clear directions and encouraging students to learn and do their activities by themselves got the highest rate. Teachers' clear instructions will help the students accomplish the objectives of the lesson or goals of a given task. There are cases that learners could not perform their assigned task because they did not understand the directions or instructions thus, teachers should ensure that they give clear and direct instructions. Furthermore, teachers are highly encouraged to design and provide activities that will promote "independent learning." Providing opportunities for students to actively construct 
meaning and connecting school work to the real world make students more engaging thus increasing self-esteem and motivation (Uhl in Overby, 2011). Students who are continuously challenged and actively involved develop higher thinking and life-long learning skills.

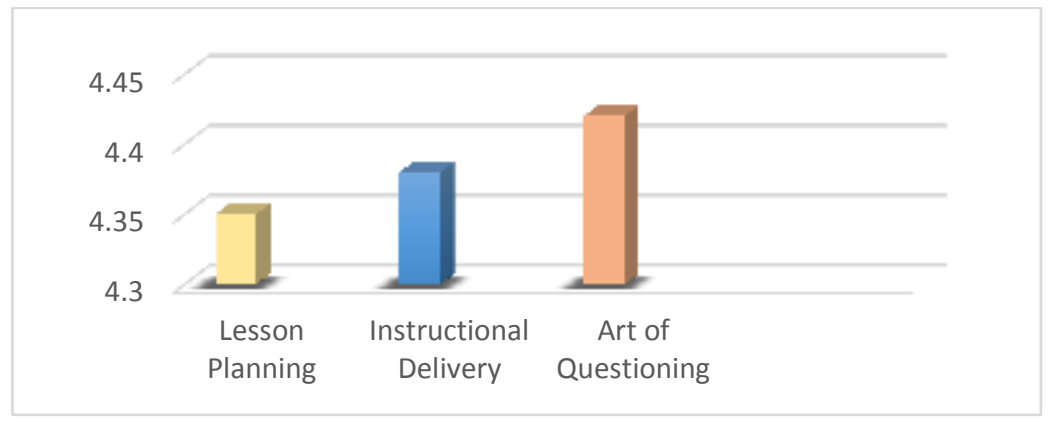

Figure 1. Teachers' pedagogical knowledge

Along with the art of questioning, teachers have the ability to formulate good and clear questions in order to target the desired student's answers. It should be noted that after asking questions, waiting time is important since students still need to comprehend the query and process their answers. Furthermore, learners should be trained to assess their own performance or their classmates' performance. The competency in enhancing the distinguished answers and showing them to the learners to take their advantage could be improved by designing activities that will let the class question the validity of the answers of their classmates. Teachers should not tell the class outright whether their answers are right or wrong. When students learn to question things they further develop critical thinking skills and creativity. It is in accordance with the ideas of Reza, et al. (2011) that questioning deepens the learning process and comprehension, promotes imagination and problem-solving, satisfies the sense of curiosity, and increases creativity.

Teaching competencies should not only focus on teaching as an expert on content knowledge but also as a facilitator of learning processes (Tigelaar, et al., 2004). Moreover, measuring and discussing teachers' competencies are highly significant to improve the teaching-learning process in school (Selvi, 2010).

\section{CHALLENGES ENCOUNTERED BY SCIENCE TEACHERS}

The top three (3) challenges encountered by the teachers along with the $\mathrm{K}$ to 12 Science curriculum are the following: lack of laboratory equipment and chemicals, lack of instructional materials such as books, projectors, etc, and a limited number of classrooms (Table 7). These identified challenges are perennial problems of DepEd teachers. Some teachers claimed that they have few laboratory equipment such as microscopes, test tubes, etc. but, they did not have a supply of chemicals which curtailed them from doing laboratory experiments. Most of the high schools had no separate laboratory room, teachers utilized their classrooms for laboratory activities/experiments. Moreover, some teachers declared that they have enough modules and books for the students however, they had a very limited number of available projectors and televisions. Teachers' desire to utilize technology in teaching is restrained because of this problem.

Table 7. Teachers' encountered challenges

\begin{tabular}{|l|c|c|c|}
\hline Parameter & WM & Int & Rank \\
\hline Spiral progression of topics & 3.80 & $\mathrm{~A}$ & 9 \\
\hline $\begin{array}{l}\text { Use of learning modules and } \\
\text { technology }\end{array}$ & 3.88 & $\mathrm{~A}$ & 6 \\
\hline $\begin{array}{l}\text { Grading System which is based } \\
\text { on level of proficiency }\end{array}$ & 3.68 & $\mathrm{~A}$ & 12 \\
\hline $\begin{array}{l}\text { Heavy teaching load (beyond the } \\
\text { minimum load) }\end{array}$ & 3.93 & $\mathrm{~A}$ & 5 \\
\hline $\begin{array}{l}\text { Other assigned } \\
\text { tasks/designation }\end{array}$ & 3.87 & $\mathrm{~A}$ & 7 \\
\hline Many required paper works & 4.20 & $\mathrm{~A}$ & 4 \\
\hline $\begin{array}{l}\text { Lack of instructional materials } \\
\text { such as books, projectors, etc }\end{array}$ & 4.37 & $\mathrm{SA}$ & 2 \\
\hline $\begin{array}{l}\text { Lack of laboratory equipment } \\
\text { and chemicals }\end{array}$ & 4.47 & $\mathrm{SA}$ & 1 \\
\hline A limited number of classrooms & 4.30 & $\mathrm{SA}$ & 3 \\
\hline $\begin{array}{l}\text { Scheduling of classes (not } \\
\text { teacher-friendly) }\end{array}$ & 3.81 & $\mathrm{~A}$ & 8 \\
\hline
\end{tabular}




\section{Legend:}

\begin{tabular}{|l|c|c|c|}
\hline $\begin{array}{l}\text { Sudden change in the class } \\
\text { schedule without prior } \\
\text { consultation }\end{array}$ & 3.75 & A & 11 \\
\hline $\begin{array}{l}\text { Limited time allotted for the } \\
\text { subject }\end{array}$ & 3.76 & A & 10 \\
\hline
\end{tabular}

4.21-5.00 Strongly Agree (SA); $3.41-4.20 \quad$ Agree (A); $2.61-3.40$ Neutral (N);

$1.81-2.60$ Disagree (D); $1.00-1.80$ Strongly Disagree (SD), Int- Interpretation,

WM-Weighted Mean

Shortage of classrooms is another perennial problem. Despite the efforts of the government to increase the budget for education still more classrooms are needed due to the 2 additional years in basic education. In fact, the current Education Secretary acknowledged the shortage and attributed it to an increase in enrolment every year. It was confirmed by a few respondents who mentioned that they need to increase the class size to 60 to accommodate more students. instruction.

These challenges are experienced by teachers for many decades and curtailed them to deliver quality

\section{CONCLUSION AND RECOMMENDATIONS}

The majority of the DepEd Science had very high competencies in Biology and Earth Science, and high competencies in Physics and Chemistry. However, they still need to deepen their understanding of some physics and chemistry concepts such as light and electricity, circular motion, the concentration of solutions, projectile motion, and conservation of linear momentum. Proficiency in basic competencies is necessary to master higher competencies. Conduct training or seminar-workshops on identified selected Science concepts is highly suggested.

They had very high competencies in pedagogical knowledge in terms of lesson planning, the art of questioning, and instructional delivery however, they should provide collaborative and empowering activities to further enhance students' critical thinking skills.

Shortage of classrooms, lack of laboratory equipment and projectors, and no supply of chemicals are challenges faced by teachers for decades and should be addressed for them to deliver quality instruction. Continued support from the government and other stakeholders such as mall owners, Parent-Teacher Association (PTA), etc. could be tapped for financial assistance for new buildings and immediate purchase of the needed chemicals, projectors and other instructional materials.

\section{REFERENCES}

1. Baumert, et al. (2010). Teachers' mathematical knowledge, cognitive activation in the classroom, and student progress. American Education Research Journal, 47(1), 133-180.

2. Bruner, J. S. (1960). The Process of Education. London, Cambridge, MA: Harvard University Press

3. Cabansag, M. G. (2014). Impact Statements on the K-12 Science Program in the Enhanced Basic Education Curriculum in Provincial Schools. Journal of Arts, Science and Commerce 5 (2): 29-39

4. Capilitan, D., Cabili, M., \& Sequete, F. Jr. (2015). A Review on the Issues in the Implementation of K+12 Science Curriculum: A Baseline Study. Accessed February 10, 2018. https://www.researchgate.net/publication/308019509_A_REVIEW_ON_THE_ISSUES_IN_THE_IMPLEMENTATI ON_OF_K12_SCIENCE_CURRICULUM_A_BASELINE_STUDY

5. Cheung, A. \& Wong, P. (2012). Factors Affecting the Implementation of Curriculum Reform in Hong Kong: Key Findings from a Large-Scale Survey Study. International Journal of Educational Management 26 (l): 39-54

6. Ferido, M. (2015). The Spiral Progression Approach in Science. Accessed February 15, 2018. http://ceap.org.ph/upload/download/20137/1371501831.pdf

7. Gray, A. (n.d.) Constructivist Teaching and Learning. SSTA Research Centre Report: 97-107

8. Hill, H., Rowan, B., \& Ball, D. L. (2005). Effects of teachers' mathematical knowledge for teaching on student achievement. American Educational Research Journal, 42(2), 371-406.

9. Kolb, D. A. (1984). Experiential Learning: Experience as the Source of Learning and Development. Englewood Cliffs, NJ: Prentice-Hall

10. König, J., Blömeke, S., Paine, L., Schmidt, W.H., \& Hsieh, F.-J. (2011). General pedagogical knowledge of future middle school teachers: On the complex ecology of teacher education in the United States, Germany, and Taiwan. Journal of Teacher Education, 62(2), 188 -201

11. $K$ to 12 Science Curriculum Guide. Retrieved from https://www.deped.gov.ph/wpcontent/uploads/2019/01/Science-CG_with-tagged-sci-equipment_revised.pdf

12. Provincial Government of Camarines Sur Official Website. Accessed March 2, 2018. Retrieved from http://www.camarinesSur.gov.ph/profile.php

13. Resurreccion, J. \& Adanza, J. (2015). Spiral Progression Approach in Teaching Science in Selected Private and Public Schools in Cavite. Proceedings of the DLSU Research Congress 3: 1-12 
14. Selvi, K. (2010). Teachers' Competencies. Cultura. International Journal of Philosophy of Culture and Axiology 7 (1): $167-175$

15. Shahani, L. (2017). The Challenges of Basic Education: Dealing with K-12 Conjugations." Accessed February 15, 2018. Retrieved from http://www.philstar.com/opinion/2015/06/15/1466151/challenges-basic-educationdealing-k-12

16. Taber, K. S. (2012). Teaching Secondary Chemistry $2^{\text {nd }}$ ed. London: Hodder Education

17. The K to 12 Basic Education Program. Accessed February 10, 2018. Retrieved from http://www.gov.ph/k-12/

18. Tigelaar, D., Dolmans, D., Wolfhagen, I., and van der Vleuten, C. (2004). The Developmental and Validation of a Framework for Teaching Competencies in Higher Education. Higher Education. The International Journal of Higher Education and Educational Planning 48 (2): 253-268

19. Voss, T., Kunter, M., \& Baumert, J. (2011). Assessing teacher candidates' general pedagogical/ psychological knowledge: Test construction and validation. Journal of Educational Psychology, 103(4), 952-969

20. Zolfaghari, A. R., Fathi, D., and Hashemi, M. (2011). Social and the Role of Creative Questioning in the Process of Learning and Teaching. Procedia - Social and Behavioral Sciences 30: 207 